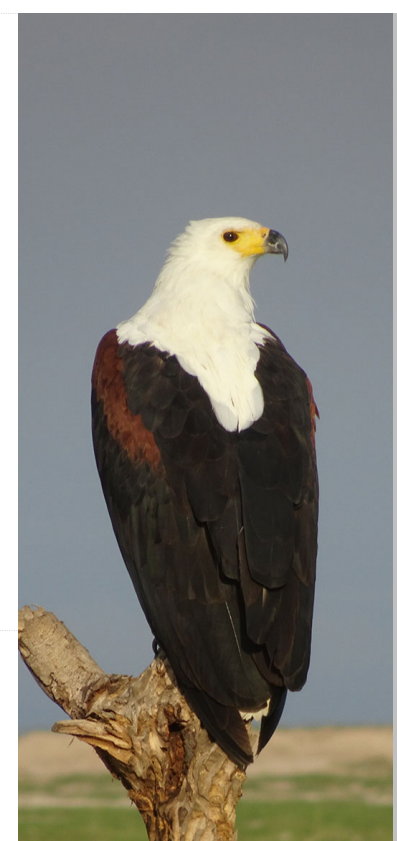

\title{
AREA-BASED CONSERVATION BEYOND 2020: A GLOBAL SURVEY OF CONSERVATION SCIENTISTS
}

\author{
Stephen Woodley* ${ }^{1}$, Nina Bhola ${ }^{2}$, Calum Maney $^{2}$ and Harvey Locke ${ }^{1}$ \\ *Corresponding author: stephen.woodley@wcpa.iucn.org \\ ${ }^{1}$ World Commission on Protected Areas, International Union for Conservation of Nature, \\ Rue Mauverney 28, 1196 Gland, Switzerland \\ ${ }^{2}$ United Nations Environment Programme World Conservation Monitoring Centre (UNEP- \\ WCMC), 219 Huntingdon Rd, Cambridge CB3 ODL, UK
}

\section{ABSTRACT}

We surveyed 335 conservation scientists, from 81 countries, in English, French and Spanish for views on area-based conservation relating to the Strategic Plan for Biodiversity 2011-2020 of the Convention on Biological Diversity and potential future targets, especially a successor to Aichi Target 11. The results can be summarised as follows:

1. Nearly unanimously, area-based or in-situ conservation is considered to be important to conserve biodiversity (99 per cent).

2. All of the qualitative aspects of Target 11 are well supported, with strongest support for areas of importance for biodiversity (e.g. Key Biodiversity Areas); ecological connectivity; integration with broader landscapes and seascapes; and effective management.

3. Future area-based conservation targets should include large-scale conservation networks that include connectivity between protected areas, protection of endangered and threatened species or ecosystems, and ecologically intact wilderness areas.

4. Various methods from conservation biology were considered useful to establish area-based targets, with systematic conservation planning receiving the greatest support.

5. There is very strong agreement (79 per cent) that Target 11, with its current percentage targets of 17 per cent of land and freshwater and 10 per cent of coastal and marine areas, is not adequate to conserve biodiversity.

6. Conservation scientists showed very strong support for large-scale percentage area conservation targets, in the order of 50 per cent of the Earth.

Key words: Aichi Targets, Target 11, area-based conservation, post-2020 global biodiversity framework, systematic conservation planning, protected areas

\section{INTRODUCTION}

There is considerable interest in the next generation of conservation targets that will replace the Convention on Biological Diversity's (CBD) Aichi Targets when they are reviewed in 2020, driven by the fact that we face both a global biodiversity crisis and rapidly changing climate. The Intergovernmental Science-Policy Platform on Biodiversity and Ecosystem Services (Díaz et al., 2019) reports that 75 per cent of the Earth's land surface is significantly altered, 66 per cent of the ocean area is experiencing increasing cumulative impacts, and over 85 per cent of wetlands (by area) have been lost. On average, population sizes of wild vertebrate species have declined precipitously over the last 50 years on land, in freshwater and in the sea, and around 25 per cent of species in assessed animal and plant groups are threatened (Díaz et al., 2019). In situ conservation is most represented by Aichi Target 11. Many of the drivers of biodiversity loss can be addressed through area-based conservation (Díaz et al., 2019), with protected areas being the backbone of area-based conservation (Wuerthner et al., 2015).

One hundred and ninety-five countries and the European Union have ratified the United Nations Convention on Biological Diversity (CBD), which has the conservation of biological diversity as a main goal. The 
Strategic Plan for Biodiversity 2011-2020 and its Aichi Targets are a framework for international collective action on biodiversity conservation (SCBD 2010). A conference of the CBD parties will be held in China in 2020 with the intention of agreeing on a new post-2020 strategic plan for global biodiversity. The preparatory work for that agreement is well underway.

Area-based conservation (termed in-situ conservation under the CBD) refers particularly to protected areas (PAs), and other effective area-based conservation measures (OECMs) are a central strategy under the current CBD Strategic Plan, primarily centred on Aichi Target 11: "By 2020, at least $17 \%$ of terrestrial and inland water, and $10 \%$ of coastal and marine areas, especially areas of particular importance for biodiversity and ecosystem services, are conserved through effectively and equitably managed, ecologically representative and well-connected systems of protected areas and other-effective area-based conservation measures, and integrated into the wider landscape and seascapes."

This target includes both quantitative (percentage area targets on land and sea), qualitative elements (effectiveness, equity, connectivity, representation, areas of importance for biodiversity and ecosystem services) and area-based actions (PAs and OECMs).

There is a recent history of setting conservation targets for protected and conserved areas, with conservation targets changing with evolving ideas on biodiversity and ecosystem services and the emergence of sustainable development and conservation biology (Locke, 2013; Sala et al., 2018, Wright et al., 2019). For example, the well-known targets of 10 or 12 per cent of geographical areas were based on representing samples of the Earth's ecosystems and did not include requirements for the persistence of species or ecological processes (Rodrigues \& Gaston, 2001). A 12 per cent target was developed in 1987 with the goal of protecting a representative sample of Earth's ecosystems (WCED, 1987). These targets were to further a policy agenda and were never based in science. Woodley et al. (2019) provide a discussion of science-based vs. policy-based targets.

To assist the global discussion on the next generation of global conservation targets, the International Union for Conservation of Nature's (IUCN) World Commission on Protected Areas (WCPA) established the Beyond the Aichi Targets Task Force (https://www.iucn.org/ protected-areas/wcpa/what-we-do/beyond-aichi- targets). Its remit includes conducting global scientific consultations and evidence reviews to seek a consensus on new global conservation targets for area-based conservation that would be meaningful for achieving the CBD's basic purpose, which is the conservation of biological diversity. As part of that effort, we conducted a global survey of conservation scientists to determine their views on the adequacy of the current Target 11 and its elements and the required elements of future conservation targets focused on area-based conservation.

\section{METHODS}

With inputs from global colleagues at a scoping meeting, we generated a survey based on the elements of Target 11, as well as considerations of other issues of importance to biodiversity conservation. They included important themes from the conservation literature, such as key ecological processes and functions; large conservation core areas for ecological integrity and resilience; ecologically intact wilderness areas; largescale conservation networks that include connectivity; geographically restricted species; species aggregations that occur during breeding and migration; threatened and endangered species; ecological processes; and calls for higher percentage targets for area-based conservation. This list was consistent with criteria used in the Key Biodiversity Area Criteria (IUCN, 2016) as well as calls in the literature for conserving intactness and processes (Watson \& Ventor, 2017), conservation networks (Mogg et al., 2019) and more ambitious percentage targets (Noss et al., 2012; Locke, 2013; Wilson, 2016). We pre-tested the survey on a group of 20 conservation scientists to reduce any error that could arrive from lack of clarity.

In order to focus on the views of conservation scientists, the survey was sent to membership lists of the Society for Conservation Biology (https://conbio.org/). The society is a global group of conservation professionals and students dedicated to facilitating, promoting and advancing the scientific study and conservation of biological diversity. It has members in almost every country in the world and the survey was sent out by email as part of regional newsletters. Respondents could take the survey in their choice of three languages, English, French and Spanish. We used the professional version of SurveyMonkey software (https:// www.surveymonkey.com/).

There were 16 questions designed to be completed in 20 minutes (a copy of the questionnaire is available in supplementary online materials). Of the 16 questions, 
eight asked for ratings of agreement with a statement based on a Likert scale response. The first four questions were designed to understand the experience and geographic location of the respondent. Seven questions included open comment fields and one question was only an open comment question asking for any additional comments. There were three questions on the general importance of area-based conservation. The survey included an explanation of all the terms used in the questions including "area-based conservation, protected areas, other effective areabased conservation measures, and areas for connectivity conservation". All the questions were on protected areas, with no differentiation between land and sea.

Five of 16 questions asked for a response based on a seven-point scale from 1 (highest importance) to 7 (least important) and three questions used a five-point rating scale ranging from 1 (highest importance) to 5 (least important). The choice of a 5 or 7-point scale was based on our estimate of the likely range of responses to an individual question. Likert scale questions were analysed by the percentage of respondents who agreed with each element of the scale, and graphs were prepared using the Likert package in $\mathrm{R}$. The data for the Likert plots were visualised and written to .pang files using ggplot2.

Question results were subjected to a Kruskal-Wallis test to determine differences between the three language groups or geography (by continent). This test asks if the different groups of respondents scored a question higher or lower than the other groups did. If there was a difference recorded by the Kruskal-Wallis test, we then used a Dunn test (using the $\mathrm{R}$ package Dunn. Test), which takes each group pair (e.g. English vs. Spanish

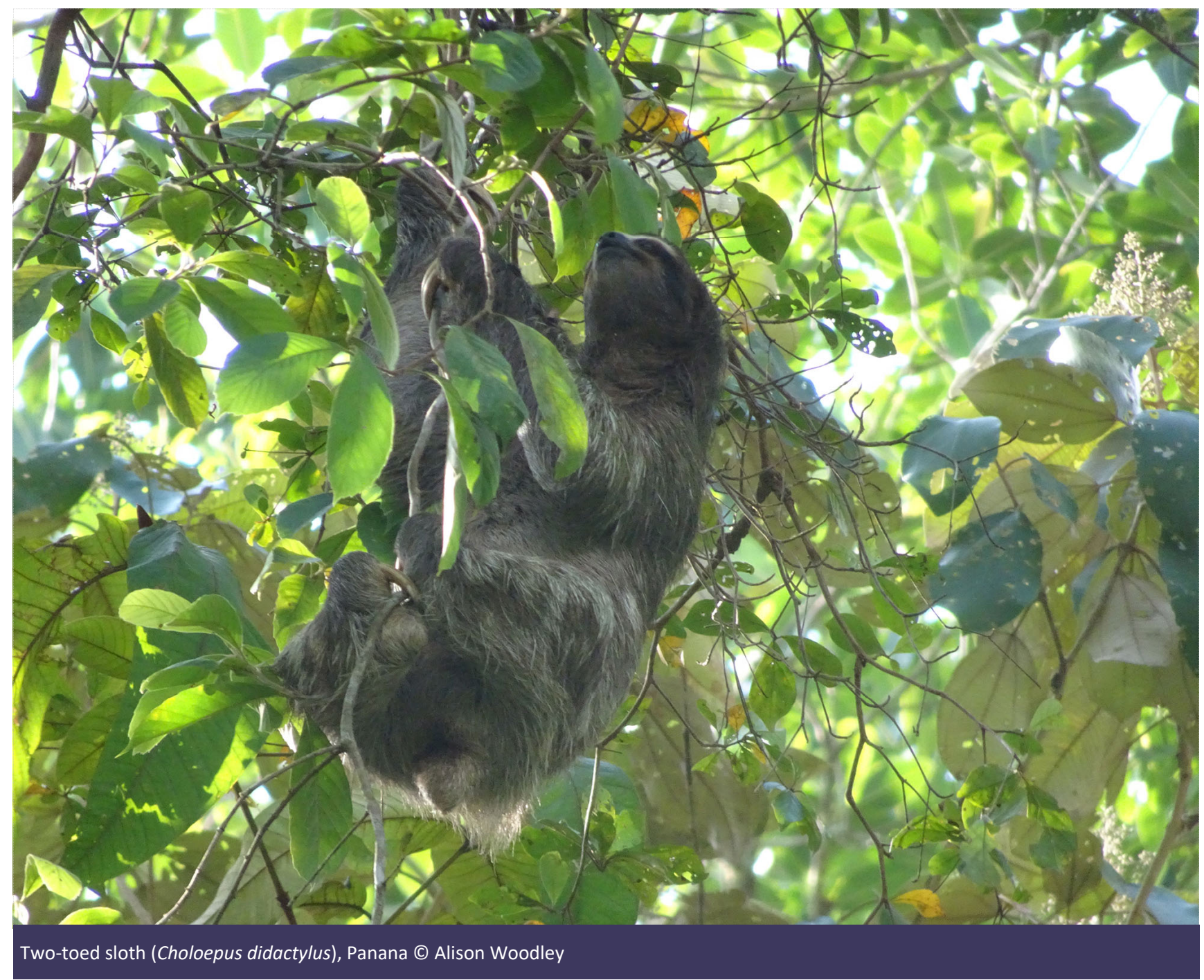


respondents) and asks if there is a difference, making a table of values with an average difference $(\mathrm{Z})$ and a significance (p).

\section{RESULTS}

We received responses from 335 scientists, located in 81 countries with good distribution across continents. The survey was part of several regional mailings sent to over 2,000 email addresses. However, the actual response rate is unknown as we have no information on how many of the emails were actually read or how many emails were current. The highest percentage responses were from Europe (25 per cent) and North America (24 per cent), with other continents (Africa (15 per cent), South and Central America (18 per cent), Asia (10 per cent) and Oceania (7.2 per cent)) being reasonably represented. By choice of language, there were 260 English, 53 Spanish and 22 French respondents. Respondents were mostly academic (41.2 per cent) or from civil society (36 per cent), with smaller numbers from government (14 per cent), the private sector (7 per cent), and indigenous and community groups (2.3 per cent). The largest percentage of the respondents worked at the regional level (32 per cent), with 20 per cent each working locally or nationally, and 28 per cent working internationally.

The results from the opinion questions on area-based conservation for the survey are as follows:

\section{Question 1: From your perspective, how important is area-based conservation to the conservation of biological diversity?}

There was virtually unanimous agreement from respondents that area-based conservation was important, with 89 per cent stating it was extremely important and 10 per cent saying it was somewhat important, for a total of 99 per cent.

\section{Question 2: From your perspective, why is area- based conservation important?}

Overwhelmingly, respondents said that "safeguarding species and ecosystems" was of highest importance (see Figure 1). The "delivery of ecosystem services", "maintaining our life support system", and "to adapt to climate change" also got strong support, but was well below "safeguarding species and ecosystems". The "economic value and benefits from protected areas", "preserving cultural practices, heritage and identity" and "maintaining local livelihoods" all received weaker levels of support as reasons for area-based conservation.
After questions on the importance of, and reasons for, area-based conservation, the survey then asked specific questions about Target 11 and a possible successor to Target 11.

\section{Question 3: There are a number of elements within the existing Aichi Target 11. Which elements of area-based conservation are important to retain in a revised target, beyond 2020?}

This question examined all the elements of Target 11, both qualitative and quantitative, with results shown in Figure 2. There was majority support for all the elements of Aichi 11, but differences in the overall level of support. There was strongest support to retain the elements of "areas of importance for biodiversity" and "ecologically well-connected systems of protected areas". Support for "areas are effectively managed" and "integrated into wider landscapes and seascapes" also received substantial support as did "ecologically representative", "percentage area targets" and areas of importance for ecosystem services". "Equitable management" received the relatively lowest support for retaining in a successor to Aichi 11. However, all elements of Aichi Target 11 received support for retention in a successor to Aichi Target 11.

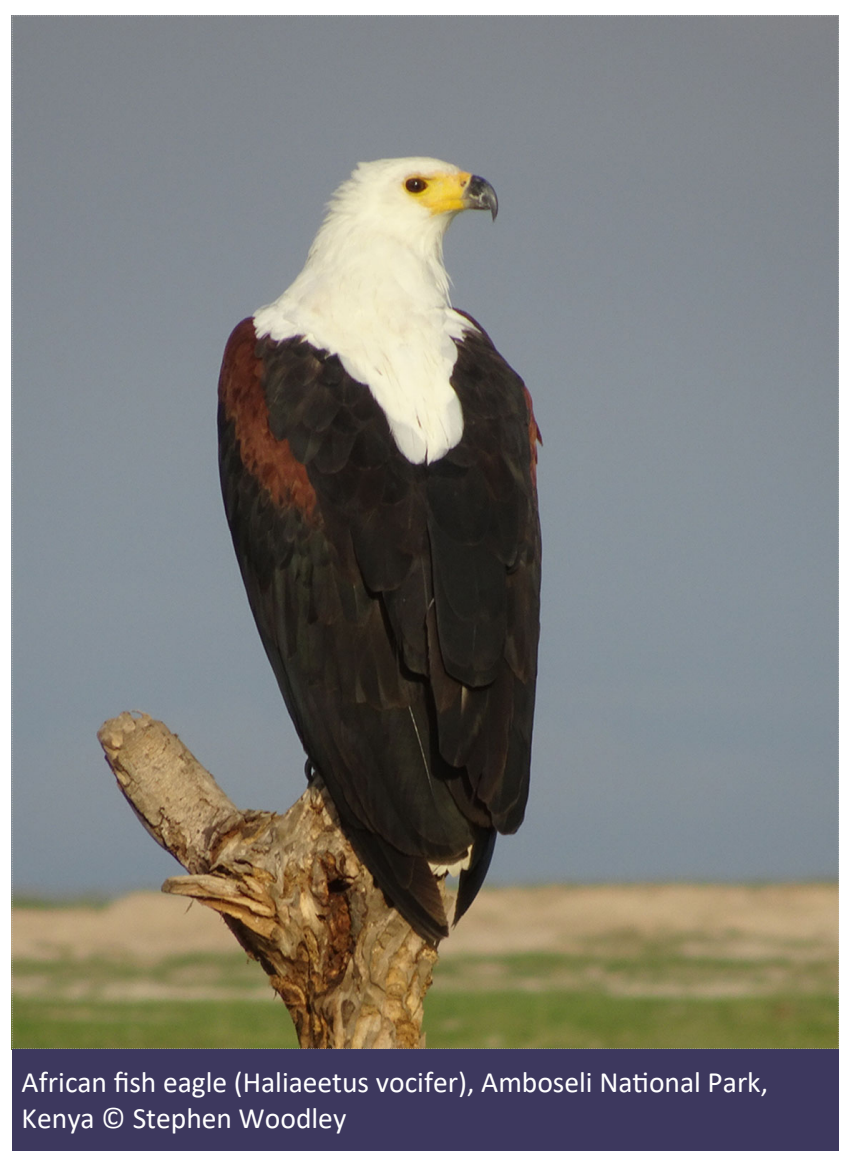


Economic value and benefits from protected areas (e.g. tourism)

Preserving cultural practices, heritage and identity

Maintaining local livelihoods

To adapt to climate change

Maintaining our life support system

Delivery of ecosystem services

Safeguarding species and ecosystems

Areas are equitably managed (e.g. fairness in decision making and benefit sharing)

Areas of importance for ecosystem services

Percentage coverage targets (e.g. $x \%$ of land and freshwater and $x \%$ marine)

The protection system is ecologically representative (e.g. includes examples of all ecological types)

Protected and conserved areas are integrated into wider landscapes and seascapes

Areas of importance for biodiversity (e.g. Key Biodiversity Areas)

Ecologically well-connected systems of protected and conserved areas

Areas are effectively managed (e.g result in measurably positive outcomes)
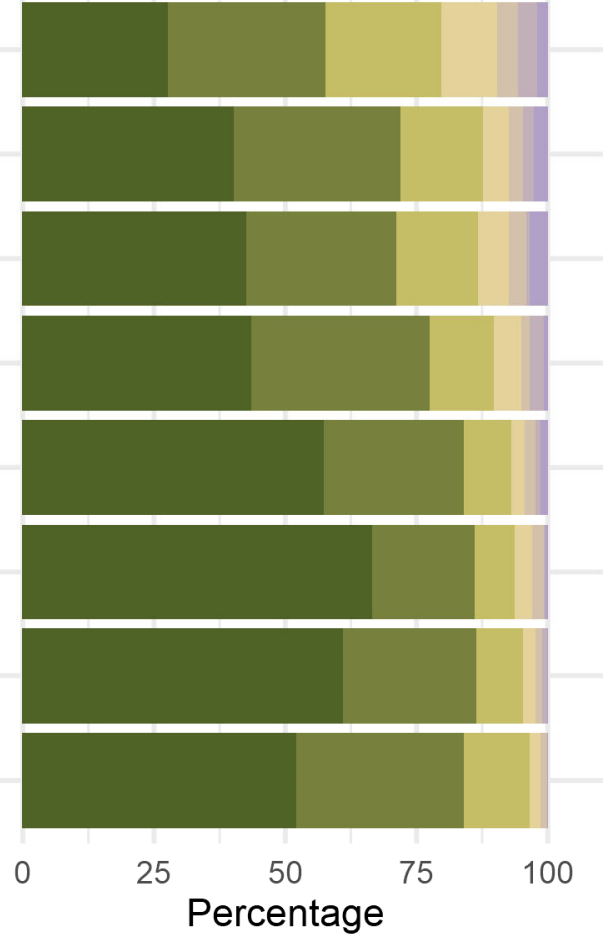

Importance

(1- highest, 7- lowest)

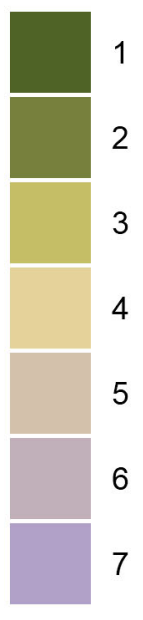

5

7

(




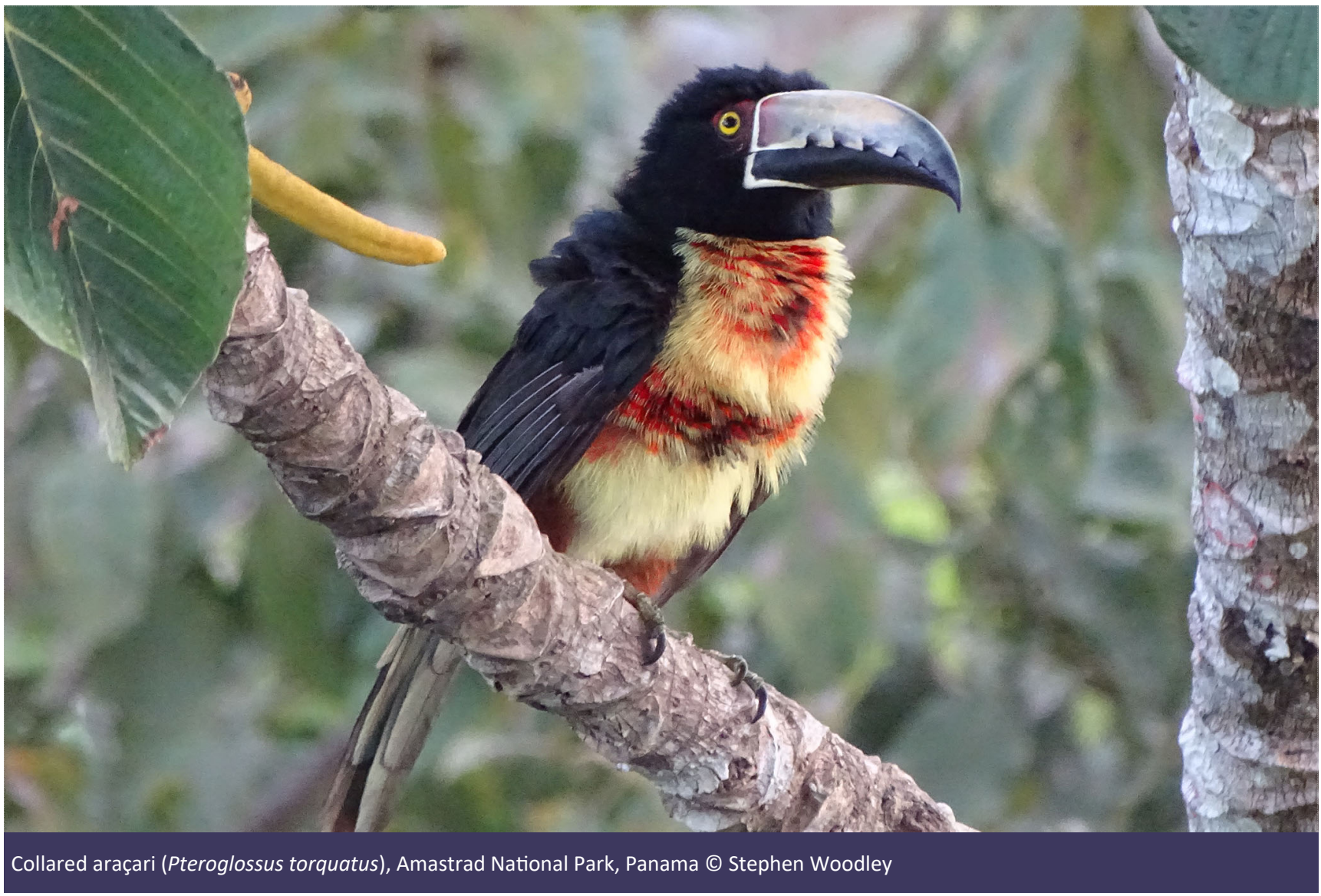

\section{Question 4: What additional elements could potentially be added to a revised area-based conservation target?}

This question examined a set of elements that could be potentially added to a successor to Target 11 , with the results shown in Figure 3.

Large-scale conservation networks that include connectivity between protected areas, protection of endangered and threatened species or ecosystems, and ecologically intact wilderness areas (in that order) were the top three missing elements that should be added to a successor to Target 11. However, all the other new elements suggested had significant support, including "large conservation core areas in each ecological region that allow for ecological integrity and resilience", "key ecological processes and functions", "protection of geographically restricted species and ecosystems" and "protection of species aggregations that occur during breeding or migration". The level of agreement in these elements was consistently strong, with little support for contrary views. This question also had an open-ended text box to allow for additional elements to be suggested, but there were few additional suggestions.
Question 5: Based on your understanding of the current ecological challenge to conserve biodiversity (genes, species and ecosystems), what do you think of the level of effectiveness of the current Aichi Target 11?

This question asked for a specific evaluation on the effectiveness of Target 11. There was overwhelming agreement (8o per cent) that 17 per cent of land and freshwater, and 10 per cent of marine areas, was not sufficient to meet the current ecological challenge for insitu conservation. Seventeen per cent of respondents thought that Aichi Target 11 was "about right to conserve global biodiversity" and three per cent responded that Target 11 was more than required to conserve global biodiversity.

Question 6: In the development of conservation targets, there are a range of considerations for how the targets should be developed. Which of the considerations listed below should influence the area-based conservation target beyond 2020?

Conservation scientists strongly agree that a future target should be evidence-based, ranking above any other considerations (Figure 4). In keeping with that 
Key ecological processes and functions (e.g. hydrological processes or natural disturbance regimes)

Large conservation core areas in each ecological region that allow for

ecosystem integrity and resilience

\section{Ecologically intact wilderness areas}

Large scale conservation networks that include connectivity between protected areas (e.g. Areas for Conservation Connectivity or ACCs)

Protection for geographically restricted species or ecosystems

Protection of species aggregations that occur during breeding or migration

Protection of threatened and endangered species or ecosystems (e.g. IUCN Red List)
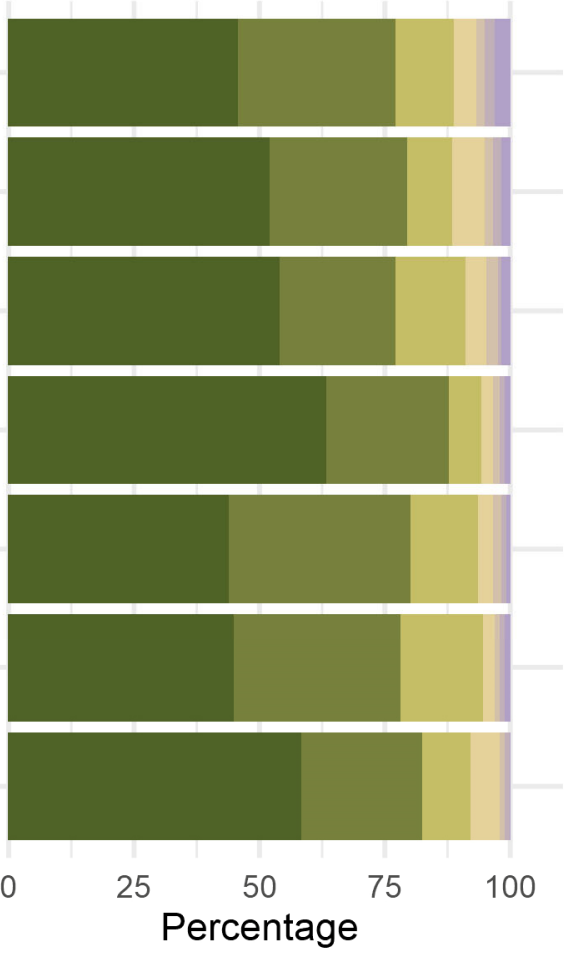

Importance (1- highest, 7- lowest)
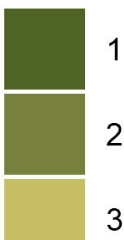

4

5

6

7

Figure 3. Summary of responses to Question 4, "What additional elements could potentially be added to a revised area-based conservation target?"

Simple: the target should be less complex than the current Target 11

Comprehensive: the target should include details on all the necessary elements

Measurable: every element of the target should be able to be measured and tracked

Evidence Based: the target should be developed on the best available science and traditional knowledge
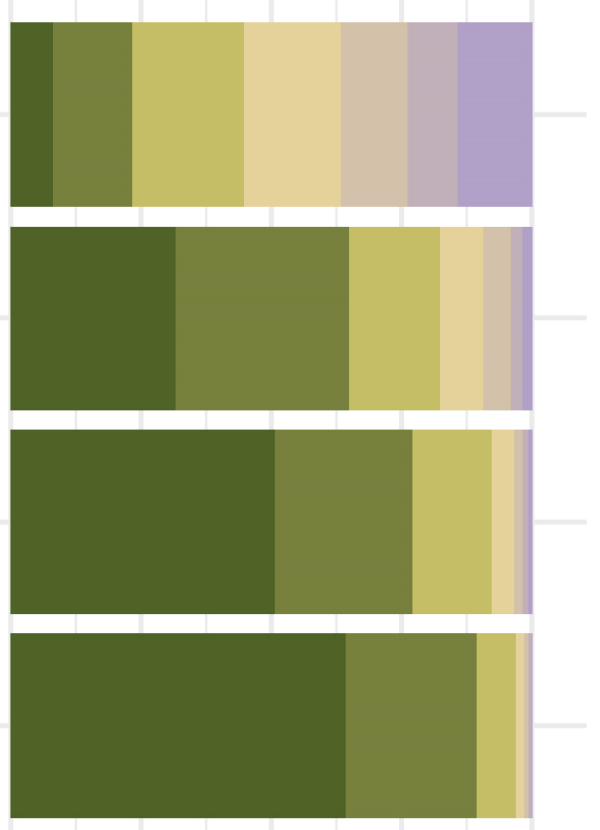

100

\section{Importance}

(1- highest, 7- lowest)

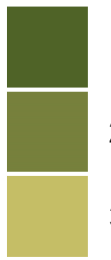

1

2

3

4

5

6

7

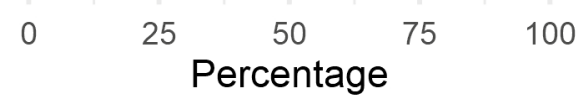

Figure 4. Summary of responses to Question 6, "Which of the considerations listed below should influence the areabased conservation target beyond 2020?" 
view, there was also support for the target being measurable. Conservation scientists were less certain about comprehensive details of all the necessary elements and generally did not support making a successor to Target 11 less complex than the current target.

\section{Large percentage conservation targets}

The survey then moved on to ask specific questions about large percentage area targets for conservation with the following questions:

\section{Question 7: To what extent to do you agree with large percentage area-based targets?}

The respondents were provided with the following background to this question: "In recent years, there have been calls from the conservation community to dramatically scale up area-based conservation. The Nature Needs Half movement calls for at least half the Earth to be protected in an interconnected way (Locke, 2013). A similar target is being proposed by the E.O. Wilson Foundation detailed in the book 'Half-Earth: Our planet's fight for life' (Wilson, 2016). At the World Parks Congress in 2012, the Promise of Sydney called for full protection of 30 per cent of the oceans. These large area-based targets are a significant increase from the existing Aichi Target of 17 per cent of land and freshwater and 10 per cent of coastal and marine ecosystems". They were then asked, "To what extent do you agree with large percentage area-based targets?”

Responses to this question showed very strong support by conservation scientists for large percentage areabased targets (Figure 5). Combining response categories 1 and 2, 76 per cent of respondents strongly agreed or agreed that large area-based targets were very important for conservation.
Question 8: If \% area is to be established for a future area-based conservation target, what is the best approach to arrive at a \% area of land or sea to protect?

Respondents rated a set of possible methods to determine area-based targets (Figure 6). There was a reasonable level of support for all the four methods proposed. The systematic conservation planning approach was the most strongly supported method, followed by the use of ecological models. There was less support for population viability analysis and speciesarea curves, but the strongest view was that all these approaches had value.

\section{Differences in language and continent}

We tested for differences in language groups and geography (continent) of the respondents. There were some significant differences in the weights of response for individual responses to question elements by continent and language group in five of the questions and 14 of the responses. These are summarised in tabular form in the online Supplemental Materials. The results reflect regional and linguistic differences in perspective. For example, in North America and Europe, in response to the question, "From your perspective, why is area-based conservation important?" there is stronger focus on "maintaining our life support system" than in Latin America. In Latin America and Africa, there was more weight on "preserving cultural practices, heritage and identity", "maintaining livelihood" and "the economic value of protected areas". For the question on "From your perspective, how important is area-based conservation to the conservation of biological diversity?" there were a range of regional and linguistic differences in the rate of response. However, there was also widespread agreement between all languages and continents on the overall response that area-based conservation was highly important. There were also

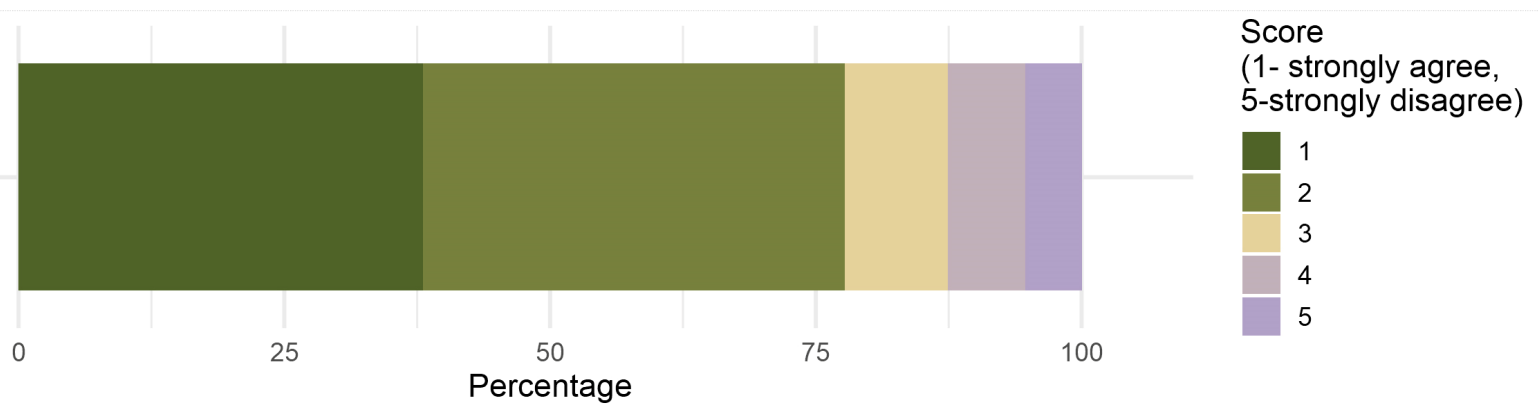

Figure 5. Summary of responses to Question 7, "To what extent to do you agree with large percentage area-based targets?" 
None of the above have value.

Population viability analysis using area demanding species such as large carnivores and umbrella species.

All of the above have value.

Species area curves that are calculated for each ecological region with an aim to represent a high \% of all species in area-based conservation systems.

Systematic conservation planning for each ecological region using a series of ecological and social goals.

Based on modelled outcomes for achieving all the elements of the new target, such as representivity, connectivity and areas important for biodiversity.
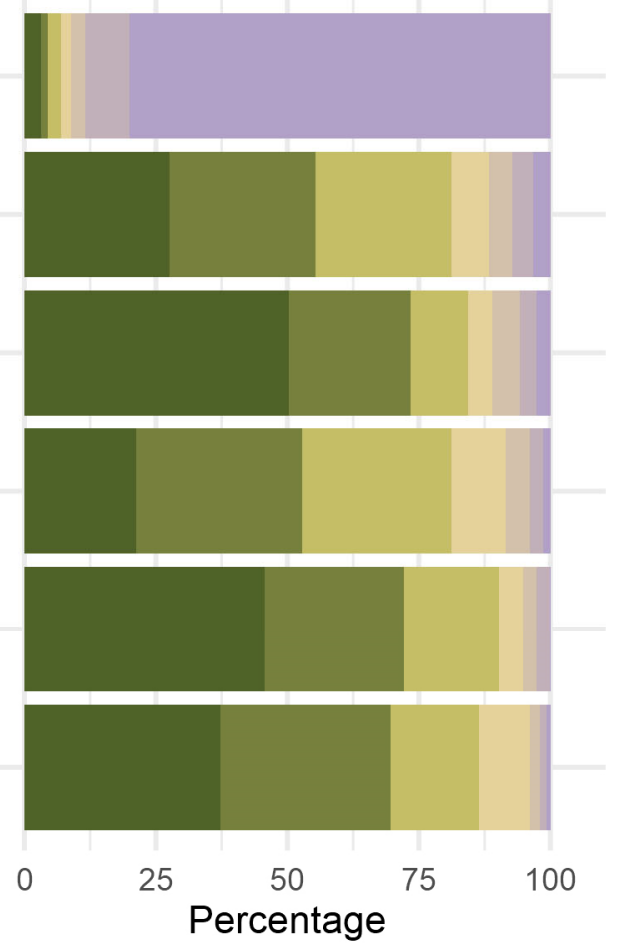

Importance (1- highest, 7- lowest)

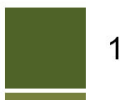

2

3

4

5

6

1
2
3
4
5
6
7
4

\section{Figure 6. Summary of responses to Question 7, "If \% area is to be established for a future area-based conservation target, what is the best approach to arrive at a \% area of land or sea to protect?}

differences on the importance of in-situ conservation for "ecosystem services".

These differences in response rates are relatively subtle. The key result was, despite some regional and linguistic differences in relative weights of responses, that the overall pattern of answers was the same. There were no major changes to the overall pattern of the answers between continents and linguistic groups.

\section{DISCUSSION}

This is the first global survey of the opinions of conservation scientists on the question of area-based conservation targets. The results show a rather unified view among conservation scientists regarding in-situ conservation of biodiversity and the value of ambitious percentage targets for area-based conservation. The strong cohesion is remarkable, given it represents a sample from 81 countries who chose to respond in three different languages, with scientists working at a range of spatial scales and for a range of sectors.

The results of the global survey of conservation scientists can be summarised as follows:

1. Area-based conservation is considered to be essential for a variety of conservation values. The degree of support from respondents is very close to unanimous with 99 per cent saying area-based conservation was very or somewhat important. This clearly favours a land sparing approach to conservation (Phalan et al., 2011), where some areas are set aside from the transformational aspects of the human enterprise, as opposed to a land sharing approach where the entire surface of the Earth is managed in a sustainable manner for a wide range of values.

2. There is very strong agreement that high percentage targets for area-based conservation are valuable (76 per cent) and that Aichi Target 11, with an area-based target of 17 per cent of land and freshwater and 10 per cent of coastal and marine areas is not adequate to conserve biodiversity (8o per cent agreement). This survey finding is very consistent with the published literature, where several authors have found the 17 per cent and 10 per cent targets inadequate, either on land (Noss et al., 2012; Butchart et al., 2015) or in the ocean (O'Leary et al., 2016).

3. The qualitative aspects of Aichi 11 are generally well supported, in particular a focus on area of importance for biodiversity (e.g. Key Biodiversity 
Areas) and ecological connectivity. However, all the qualitative elements from the current targets were well supported by the majority of respondents.

4. When asked about additional biological considerations to add to a successor for Target 11, there was strong support for all elements suggested. The leading additions were large-scale conservation networks that include connectivity between protected areas, and protection of endangered and threatened species. There was also strong support for ecologically intact wilderness areas which has been called for as a priority by Watson et al. (2018).

5. Conservation scientists showed strong support (76 per cent strongly agreed or agreed) for large percentage conservation targets, along the lines of 50 per cent of the Earth suggested by Locke (2013); Wilson (2016) and Dinnerstein et al (2019). This is interesting because such proposals are sometimes interpreted as impractical in a world of approximately 7.7 billion people. There was support for all methods of determining the percentage needed, with systematic conservation planning the most favoured approach. This agreement on large percentage targets determined by a variety of methods is consistent with the findings of a recent structured review of the literature for percentage area-based targets required to conserve natural values on land and sea (Woodley, 2019).

6. There was strong agreement that the next generation of conservation targets should be evidence-based, measurable and cover a broad range of elements important to the effective conservation of biodiversity.

7. There were some differences in the weight of responses to five questions between continents and linguistic groups. However, the difference in responses did not change the direction of any of the overall responses. In general, there is more emphasis on the utilitarian values of protected areas, including economic and ecosystem services, in Africa, Asia and Latin America than in North America and Europe.

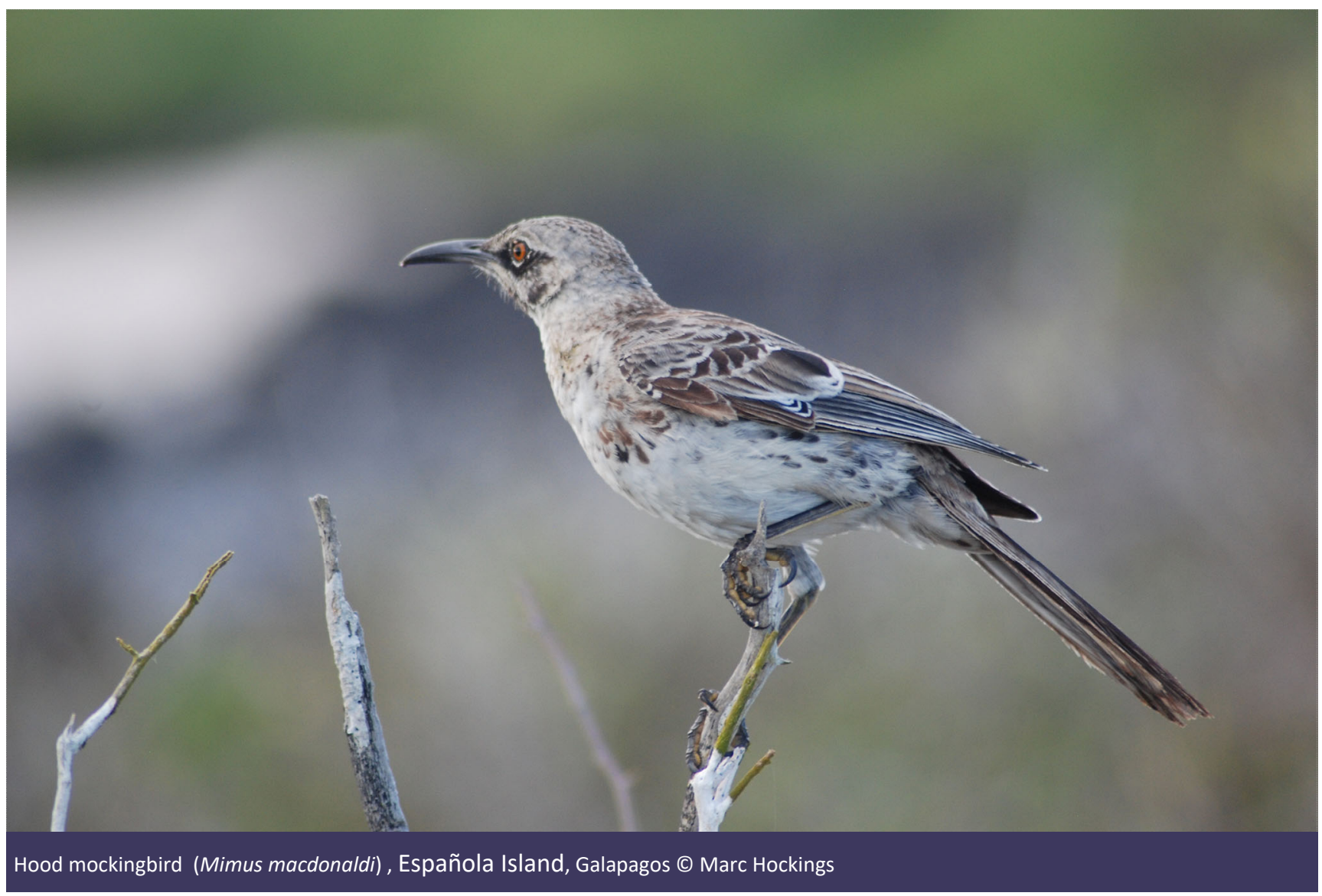




\section{SUPPLEMENTARY ONLINE MATERIAL}

Survey questionnaire.

\section{ACKNOWLEDGEMENTS}

This survey was conducted under the auspices of the Beyond the Aichi Targets Task Force of the World Commission on Protected Areas of the IUCN. The idea for the survey came from a Task Force Workshop held at Vilm, Germany hosted by the International Academy for Nature Conservation of the German Federal Agency for Nature Conservation. We are grateful for the support of the Academy and the Task Force members who participated in the meeting. We are also grateful to the Society for Conservation Biology for distributing this survey through their networks. We are thankful for the support of Iain MacGillivray and Dr Noha Faud in providing translations for the survey.

\section{ABOUT THE AUTHORS}

Stephen Woodley has worked in environmental conservation as a consultant, a field biologist, researcher, and first Chief Scientist for Parks Canada. In 2011, Stephen began working as Senior Advisor to the Global Protected Areas Program of the IUCN and continues that work as Vice Chair for Science and Biodiversity of IUCN's World Commission on Protected Areas. The work focus is to understand the role of protected areas as solutions to the current global conservation challenges.

Nina Bhola works at the United Nations Environment Programme World Conservation Monitoring Centre (UNEP-WCMC). As well as her work on the post-2020 framework, she also manages a GEF-funded project on areas-beyond national jurisdiction focusing on areabased planning and ocean governance. Nina completed a $\mathrm{PhD}$ focused on investigating the effects of climate and land use changes on the spatial-temporal dynamics of wildlife and vegetation within protected areas and their surrounding pastoral rangelands in Africa.

Calum Maney joined the United Nations Environment Programme World Conservation Monitoring Centre (UNEP-WCMC) in 2018. His work there ranged from ecological modelling around agroforestry landscapes to building spatial frameworks for identifying priority conservation landscapes around the world. He is now a Cambridge University MPhil candidate investigating ways to link the commitments countries make to nature to their impact on biodiversity.

Harvey Locke is Chair of the IUCN-WCPA's Beyond the Aichi Targets Task Force. For the last three years, he has led international consultations on post-2020 conservation targets to protect the earth. He is cofounder of the Yellowstone to Yukon Conservation Initiative and the Nature Needs Half Movement. Named one of Canada's leaders for the 21st century by Time Magazine, he has received many awards for his work including IUCN's Fred M. Packard International Parks Merit Award. He lives in Banff National Park, Canada.

\section{REFERENCES}

Butchart, S.H., Clarke, M., Smith, R.J., Sykes, R.E., Scharlemann, J.P., Harfoot, M., Buchanan, G.M., Angulo, A., Balmford, A., Bertzky, B. and Brooks, T.M. (2015). Shortfalls and solutions for meeting national and global conservation area targets. Conservation Letters 8(5); 329-337. doi.org/10.1111/ conl. 12158

Díaz, S., Settele, J., Brondízio, E., Ngo, H., Guèze, M., Agard, J., Arneth, A., Balvanera, P., Brauman, K., Butchart, S. and Chan, K. (2019). Summary for policymakers of the global assessment report on biodiversity and ecosystem services of the Intergovernmental Science-Policy Platform on Biodiversity and Ecosystem Services.

Dinerstein, E., Vynne, C., Sala, E., Joshi, A.R., Fernando, S., Lovejoy, T.E., Mayorga, J., Olson, D., Asner, G.P., Baillie, J.E.M. and Burgess, N.D. (2019). A global deal for nature: Guiding principles, milestones, and targets. Science Advances 5(4): eaaw2869. doi.org/10.1126/sciadv.aaw2869

IUCN (2016). A Global Standard for the Identification of Key Biodiversity Areas, Version 1.0. First edition. Gland, Switzerland: IUCN.

Locke, H. (2013). Nature needs half: A necessary and hopeful new agenda for protected areas. PARKS 19(2): 13-22. 10.2305/ IUCN.CH.2013.PARKS-19-2.HL.en

Mogg, S., Fastre, C. and Visconti, P. (2019). Targeted expansion of Protected Areas to maximise the persistence of terrestrial mammals. bioRxiv: $608992 . \quad$ doi: http:// dx.doi.org/10.1101/608992

Noss, R.F., Dobson, A.P., Baldwin, R., Beier, P., Davis, C.R., Dellasala, D.A., Francis, J., Locke, H., Nowak, K., Lopez, R. and Reining, C. (2012). Bolder thinking for conservation. Conservation Biology 26(1): 1-4. doi.org/10.1111/j.15231739.2011.01738.x

O'Leary, B.C., Winther Janson, M., Bainbridge, J.M., Aitken, J., Hawkins, J.P. and Roberts, C.M., 2016. Effective coverage targets for ocean protection. Conservation Letters, 9(6), pp.398-404. doi:10.1111/conl.12247.

Phalan, B., Onial, M., Balmford, A. and Green, R.E. (2011). Reconciling food production and biodiversity conservation: land sharing and land sparing compared. Science 333(6047): 1289-1291. doi: 10.1126/science. 1208742

Rodrigues, A.S.L. and Gaston, K.J. (2001). How large do reserve networks need to be? Ecology Letters 4: 602-609. doi.org/10.1046/j.1461-0248.2001.00275.x

Sala, E., Lubchenco, J., Grorud-Colvert, K., Novelli, C., Roberts, C. and Sumaila, U.R. (2018). Assessing real progress towards effective ocean protection. Marine Policy 91: 11-13. doi.org/10.1016/j.marpol.2018.02.004 
SCBD (2010). SCBD COP-10 Decision X/2. Secretariat of the Convention on Biological Diversity.

Watson, J.E. and Venter, O., 2017. Ecology: a global plan for nature conservation. Nature, 550 (7674), p.48.

Watson, J.E., Venter, O., Lee, J., Jones, K.R., Robinson, J.G., Possingham, H.P. and Allan, J.R. (2018). Protect the last of the wild. Nature 563, 27-30. doi: 10.1038/d41586-018-07183 $-6$

WCED, S.W.S., 1987. World Commission on Environment and Development. Our Common Future, 17, pp.1-91.

Wilson, E.O. (2016). Half-Earth: Our Planet's Fight for Life. WW Norton \& Company.
Woodley, S., Locke, H., Laffoley, D., MacKinnon, K., Sandwith, T. and Smart, J. (2019). A Review of Evidence for Area-based Conservation Targets for the Post-2020 Global Biodiversity Framework. PARKS 25(2): 31-44. DOI: 10.2305/ IUCN.CH.2019.PARKS-25-2SW2.en

Wright, P.A., Moghimehfar, F. and Woodley, A. (2019). Canadians' perspectives on how much space nature needs. FACETS 4: 91-104. doi:10.1139/facets-2018-0030

Wuerthner, G., Crist, E. and Butler, T. eds., 2015. Protecting the wild: Parks and wilderness, the foundation for conservation. Island Press.

\section{RESUMEN}

Entrevistamos a 335 científicos conservacionistas, de 81 países, en inglés, francés y español, para obtener opiniones sobre la conservación basada en áreas en relación con el Plan Estratégico para la Biodiversidad 2011-2020 del Convenio sobre la Diversidad Biológica y los posibles objetivos futuros, especialmente un sucesor de la Meta 11 de Aichi. Los resultados se pueden resumir de la siguiente manera:

1. De forma casi unánime, la conservación basada en áreas o in situ se considera importante para conservar la biodiversidad (99\%).

2. Todos los aspectos cualitativos de la Meta 11 cuentan con el apoyo adecuado, con un mayor grado de apoyo a las áreas de importancia para la biodiversidad (por ejemplo, áreas clave para la biodiversidad); conectividad ecológica; integración con paisajes terrestres y marinos más amplios; y gestión eficaz.

3. Los futuros objetivos de conservación basados en áreas deben incluir redes de conservación a gran escala que incluyan conectividad entre áreas protegidas, protección de especies o ecosistemas amenazados y en peligro, y áreas silvestres ecológicamente intactas.

4. De los diversos métodos de la biología de la conservación que se consideraron útiles para establecer objetivos basados en áreas, la planificación sistemática de la conservación fue la que recibió el mayor apoyo.

5. Existe un amplio consenso (79\%) en torno a que la Meta 11, con sus objetivos porcentuales actuales de $17 \%$ de tierra y agua dulce y $10 \%$ de áreas costeras y marinas, no es adecuada para conservar la biodiversidad.

6. Los científicos de la conservación mostraron un fuerte apoyo a los objetivos porcentuales de conservación de las áreas protegidas a gran escala, del orden del 50 por ciento de la Tierra.

\section{RÉSUMÉ}

Nous avons interrogé 335 scientifiques spécialistes de la conservation de 81 pays, en anglais, espagnol et français, afin de recueillir leur point de vue sur la conservation par zones en rapport avec le Plan stratégique pour la diversité biologique 2011-2020 de la Convention sur la diversité biologique et les futurs objectifs potentiels, en particulier le successeur de l'Objectif 11 d'Aichi. Les résultats peuvent être résumés comme suit :

1. Presque à l'unanimité, la conservation localisée ou in situ est considérée comme importante pour la conservation de la biodiversité (99 pour cent).

2. Tous les aspects qualitatifs de l'Objectif 11 sont bien étayés, avec un soutien plus fort pour les zones importantes pour la biodiversité (exemple: les zones clés pour la biodiversité); la connectivité écologique; l'intégration avec des paysages terrestres et des marins plus vastes; et une gestion efficace.

3. Les futurs objectifs de conservation par zone devraient inclure des réseaux de conservation à grande échelle qui assurent la connectivité entre les aires protégées, la protection des espèces et des écosystèmes menacés ou en voie de disparition, et les grands espaces sauvages écologiquement intacts.

4. Diverses méthodes issues de la biologie de la conservation ont été jugées utiles pour établir des cibles par zone, parmi lesquelles la planification systématique de la conservation a bénéficié du plus grand soutien.

5. Il existe un très fort consensus (79 pour cent) sur le fait que l'Objectif 11, avec ses cibles actuelles en pourcentage de 17 pour cent des terres et des eaux douces et de 10 pour cent des zones côtières et marines, ne permet pas de préserver la biodiversité.

6. Les scientifiques de la conservation ont montré un très fort soutien pour des objectifs de conservation à grande échelle, de l'ordre de 50 pour cent de la surface de la Terre. 